\title{
District Administrators In Urban Areas: Challenges And Success: Case Of Harare Central District .Zimbabwe.
}

\author{
Henry Mabika \\ and \\ Tawanda John Chingwanangwana
}

\begin{abstract}
In 2004 Zimbabwe introduced District Administrators in urban areas in abid to improve governance in this area. However this cadre has meet with several challenges which include lack of specific guiding legislation, lack of resources, and lackof community leadership and accountability of councils. On the other hand urban areas have benefited in areas of housing delivery organization, organization of state functions and civic protection issues. This paper is exposing these challenges and successes of the urban district administrator using the Harare Central District, Zimbabwe as case study.
\end{abstract}

\section{INTRODUCTION}

Urban areas are today faced with many challenges to include inadequate funding, cleanliness, safety, and diversity. One hopes that when Zimbabwe introduced District Administrators in urban areas and the creation of Metropolitan Provinces in 2004,itwas in abid to overcome some of these problems. Hopeful it was in abid to improve the governance of urban settings which are Harare and Bulawayo. Each of the two Metropolitan Provinces is made up of districts under the management of District Administrators. This paper is giving amicroscopic diagnosis of challenges and successes faced by District Administrators in urban areas focusing mainly on Harare Central District. There are aplethora of challenges being faced by District Administrators in urban areas especially because of the way District Administrators were institutionalized in Zimbabwe.

Governance can be defined as the management of public affairs based on defined government policies and implemented through public institutions. District Administrators were introduced in urban area to strengthen governance mechanisms and assist the decentralization of responsibilities and resources to local authority, and encouraging the participation of civil societies to achieve common objectives but this foresight is being hampered by anumber of challenges that this paper will identify.

Background

Harare Metropolitan Province was created in 2004 through the Provincial Councils and Administration Act (Chapter 29:12). It should be noted that during its inception there was the Provincial Governor (Pg) (A Political Appointee) working hand in glove with the Provincial Administrator and District Administrator (Technocrats). However, with the advent of the New Constitution the post of Provincial Governor wasreplaced with that of the Minister for Provincial Affairs.

Within the Harare Metropolitan Province thereare four Local Authorities, these include Harare City Council, Chitungwiza Municipality, Ruwa Town Council and Epworth Local Board. This alone pose as achallenge in the smooth functioning of the province.Harare Province is subdivided into five administrative districts. These include Harare Central District, Ruwa/ Epworth, Highfield, Chitungwiza, Harare North, Mabvuku/Tafara, and Harare South. The sub-division isalso the source of another problem. As there are several District Administrators managing asingle local authority. There is duplication of District Administrator's authority in Harare.

There is also the legal dilemma,whereby District Administrations (Das) are not included in the Urban Councils Act which means they are currently acting on the basis of delegated authority. Also the Acts governing their roles are not clear as to what they should do thus their roles are shrouded in obscurity. All humanitarian work within the district is carried out by Non-Governmental Organizations (Ngos) Anumber of them exist within Harare Central District. Ngoshave taken over where government ended. They are there to compliment government efforts especially in areas of development. For the complimentary role to be efficient there need to be awater tight relationship between governance institutions. In this case this is the District Administrators office, Council and the Ngos. Together they identify areas were assistance is due and those who should benefit from the various Ngos. It is against this background that the paper dissects this area. In abid to bring out the challenges and successes of the District Administrators in urban areas as observed by those working in this area narrowing to Harare Central District. 
Fig 1: District Administrators Office Hierarchy

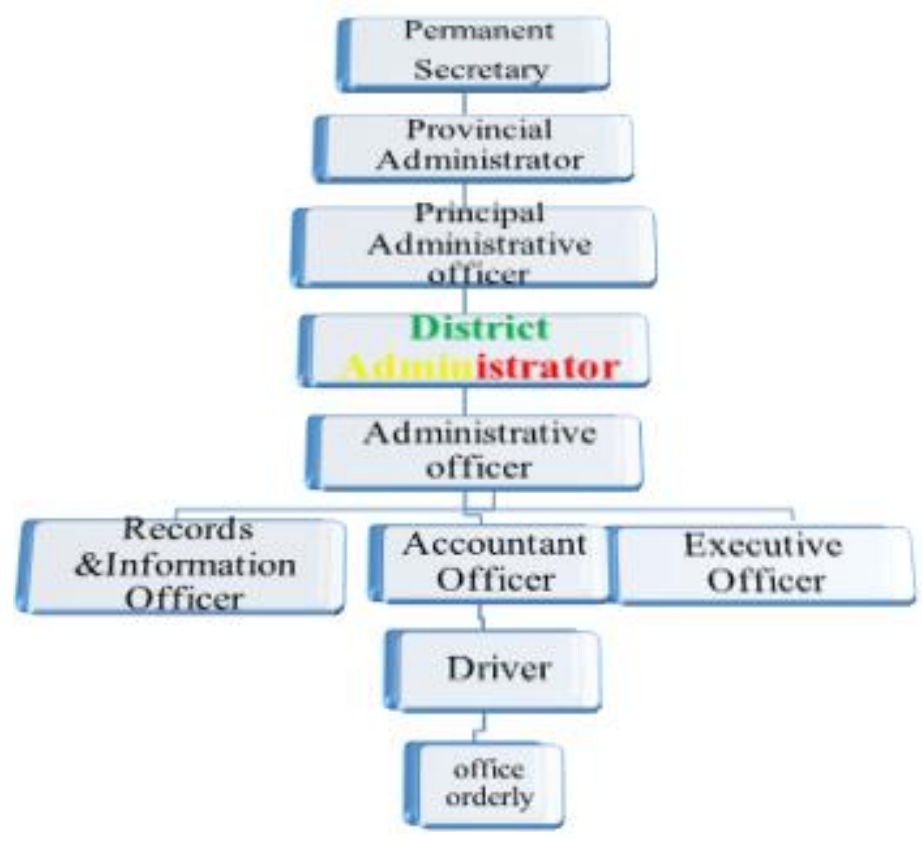

Source: Ministry Of Local Government Public Records.

\section{Provincial Administrator}

Provincial Administrator $(\mathrm{Pa})$ is appointed by the Public Service Commission and each province is assigned a Provincial Administrator, Harare Metropolitan Province has one. Provincial Administrators are appointed on merit after making applications to Public Service Commission and sitting for an interview, and authorized by section 33 of The Provincial Councils and Administration Act (1985)Provincial Administrators are also recognized by the Constitution (Kurebwa 2015). No legislation sets out the qualifications for, or duties of office, of Provincial Administrators (Matyszak, 2011). The Pa coordinates all the functions of The District Administrators and chairs The Provincial Development Committee (Section 27 of The Provincial Councils and Administration Act Chapter 29:11).

\section{District Administrator}

They form the mantle of the management team that helps the Minister in running the country on all local government issues with the mandate of coordinating multiagency plans at alocal level (Chatizain De Visser 2010). The District Administrators' are responsible for their particular district and they conduct their duties in the area that falls under their jurisdictions. There are sixty-one (61) districts in Zimbabwe (Central Statistics Office 2002). Out of the 61, there are fourteen (14) District Administrators in urban areas. That is Harare Metropolitan Province and Bulawayo Metropolitan Province.

Conceptual Framework

The History of Local Government is generally traced back to the coming in of the British South Africa Company (Bsac) in 1890(Chatiza, 2008).However the first formally established local authority was The Salisbury Sanitary Board in 1891, followed by the first Municipal Law Of 1897 (De Valk And Wekwete 1990). Matabeleland Order in Council Of 1894 saw the creation of Gwaaiand Shangani Reserves hence the beginning of colonial local government (Chatizain De Visser 2010). In terms of urban local government legislation before independence changes were made through the enactment of A Municipal Act In 1930 and The Urban Councils Act in 1973 (Chatiza 2008). It is worth to note that prior to independence, the Local Government Legislation provided for racially divided urban and rural areas, and, anymove to promote black supremacy was subjugated by the whites' supremacy policies.

The office of The Rural District Administrator came into existence after independence with the sole purpose of addressing the land conflicts in rural areas. Following the commencement of the local government reform in 1980, collective leadership in Zimbabwe has been portrayed by an abundance of covering and incongruent neighborhood authoritative structures, each with its own limits, and drawing on various wellsprings of 
authenticity, which has madefeeble and unique neighborhood establishments (Ncube 2011). As aresult there existed three decentralized structures juxtaposed together. They included The Provincial Development Committees, Ward Development Committees (Wadcos) and Village Development Committees (Vidcos), (Sithole, (1997); Mandondo, 2000 Sited in Ncube 2011). But these are not present in urban areas. Having such structures in rural areas created apool of confusion as there was agrey area on the part of the functions they had to play. Only faith could see the difference, in the same vain there existed Chiefs, Headman and Village Heads who had power over the land. Thus conflicts were rampant in communal areas as the theelected and the traditional authorities conflicted over the administration of the land (Mukamuriand Mavedzenge, 2000). It should be noted that the conflict can be traced back from The Communal Lands Act of 1982 which took the powers of the traditional authorities giving it to the elected official (Ncube 2011). By the advent of this the Government sought to restructure,creating Ministries like The Ministry of Community Development and Cooperatives (Steward e tal 1994), Directives were introduced such as the 1984-5 Prime Ministers Directives (Mandondo 2000). Lastly democratic structures were created at the grassroots level.

The Prime Ministers Directive created avenues for grassroots participation, as structures were created that is ward Development Committees (Wardcos) and Village Development Committees (Vidcos) with the motion of practicing bottom up planning and development(Chakaipa 2010). Rural Councils and District Councils were amalgamated through the Rural District Councils Act (Rdc) of 1988 (Jonga 2014). The Government passed the Traditional Leader's Act of 2000 and in the process avoiding confusion, tension and conflict of interest. Thereby giving aclearly defined role for the traditional leaders in the discharge of their duties. But all these structures are not part of the urban set up.

\section{Challenges}

\section{FIG 2:Five DAs monitoring and supervising one local authority: City of Harare}

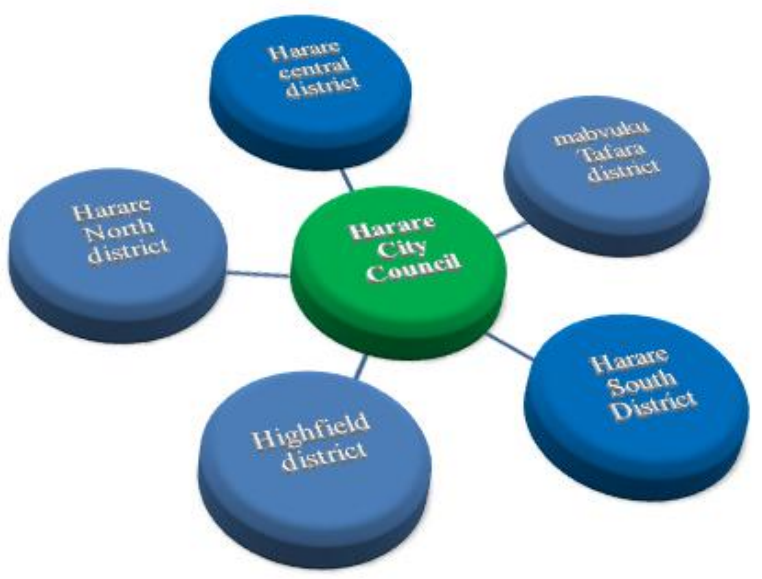

Source; Field Survey 2016 March

The above diagram represents The District Administrators for Harare Metropolitan Province monitoring one local authority Harare City Council.Harare Metropolitan Province is manned with seven District Administrators and of the seven, five monitor one local authority which is Harare City Council. Ninety percent (90\%) of the respondents argued that having such asituation brings about achallenge. Taking for example that there is The District Civil Protection Committee (Dcpc) and also The District Development Committee (Ddc) in these committees'officials from The City of Harare must sit. The challenge here is that the same official will have to attend all the five districtmeetings. The same director for example Director of Housing should be at all the districts meetings. As a resultthey tend not to attend the meetings. Even if councilwant to call the District Administrator for ameeting they are facing achallenge of who to call for the meeting. 


\section{Legislative Gap}

The Zimbabwe Institute, Local Government Policy Review (2005) suggested that The Local Government especially at sub national levels that is The District and Provincial Councils in Metropolitan Provinces should operate as an independent board that can take legal action in its name. Thus their functions should be precise and clear cut. Yet on the contrary, the Urban Councils Act Chapter 29:15 (UCA) does not recognize the functions of District Administrators in urban areas.Unlike their counterparts in rural councils under The Rural District Councils Act Chapter 29:13 (Rdc Act). Where it is clear on the functions of The District Administrators. District Administrators in rural areas have greater influence as they are given the power by the Rdc Act and yet District Administrators in urban area function under delegated authority.

In addition the Urban Council Act Chapter 29:15 (UCA) places greater emphasis on The Minister of Local Government as reflected by The Minister shall concept,unlike the rural councils. Thus currently the District Administrators in urban areas operate on the basis of delegated authority. The Minister of Local Government, Public Works and National Housing (Mlg) is of utmost importance and has too much power to the detriment of good governance (Local Government Green Paper, 2014). This is further reiterated by the clausesthat are furnished in the Urban Councils Act Chapter 29:15. The furnishing of powers has been asubject for great debate among scholars in the academic sphere. The powers of The Minister (section 53 and 314 of the UCA) include to reverse, to suspend, to rescind resolutions of council, make general regulations and give directions on matters of policy in council. Mushamba (2010) argues that these Clauses in the Act raises alot of eyebrow and questions in the legal sector. Asking questions like, when is it in the public interest to do acertain act? Furthermore in terms of section 276(1) of The Constitution (2013), subject to The Constitution and any Act Of Parliament, 'A Local Authority has the right to govern, on its own initiative, the local affairs of the people within the area for which it has been established, and has all the powers necessary for it to do so'. Thus raising the question that if the local authority has such powers then, why should there be District Administrators.

\section{Accountability Systems}

In 2003 The Minister responsible for local government directed all Urban Councils tobe accountable and report to these structures that is The Provincial and District Administrator. This move by the Minister was critiqued by Madhukucited in The Financial Gazette (February 27-March 5 2003), arguing that this approach of reporting to the sub national level Government was a death nail to the already dying democracy at the local level. Jonga (2014) argues that the creation of these structures resulted in a state of confusion and negative perceptions in the administration of urban councils. This was further reflected by the duplication of roles and overlapping of authority. That was caused by the presents of The Head Office within the Harare Metropolitan Province. Therefore urban councils remained partial and not accountable to The District Administrators. The Zimbabwean Constitution (2013) is hazy on the local government framework and lower limits and at the same time The District Administrators faces achallenge, because most of the time the Council is not accountable to them. Thus one cannot deny that it is achallenge that is being faced by The District Administrators urban Areas.

\section{Lack Of Community Leadership}

Local Government is an independent body closer to the people which influences local citizen participation. Chikerema (2012) argues that the democracy created at the local level renders the citizens freedom to participate and make decisions for the greater good of the local community. On the other hand there is absents of a clear and authoritative community leadership in urban areas. The New Constitution (2013) section 270(1) explicitly propounds that the metropolitan province has afunction to develop its province that is both social and economic development and this is achieved through The Provincial Administrator who then delegates to the District Administrator of an area concerned. Section 267(2) talks about the division of aprovince into districts. However, given such asituation, it poses achallenge to the smooth functioning of the District Administrators' office in urban areas in ensuring development. As there islack ofproper community leadership. Of which communication and community leadership at the local level is the life blood of all developments. Unlike their counterparts in rural areas who work with and through Traditional Leaders and their communication channel is clear. They will talk to the Chief and Headman of the area concerned.

\section{Resource}

Mushambaet al (2014), postulated that the revenue base has been dwindling during the last eight years,causing poor service delivery to the people. Mushambaet al (2014) goes on to say local authorities have amassive backlog of new infrastructure requirements and also need to allocate resources for the maintenance, renovations and replacement of older, deteriorating equipment. One cannot dispute the notion that due to lack of finance. There is brain drain as people migrate in search of greener pastures leading to poor service delivery. It suffices that due to resource inadequacy and the lack of apolitical will to manage the situation the District Administrators' office is inadequately resourced and lacks up to date equipment. Propounding further the issue of lack of financial resource was mainly caused by the economic crisis that hit Zimbabwe eight years ago. To such an extent that the people of Zimbabwe had abacklog ofdebts of rates and rents (Coutinhoin Jaap De Visser 
2010). As if this was not enough there came the 2013 directive to slash all debts, thisfurther stressed the already dwindled financial base for local authorities. Adding on to the above there is the issue of a decline in donor funding over the years which further exacerbate the local authorities and the district (Davison 2001). The issue of a decline in donor funding led to poor service delivery.Zimbabwe Country Analysis Working Document Final Draft (2014), reflects that with the advent of the realization that funding from the donors was cut, the government sort to instill and build resiliency in the Zimbabwean population through the policy framework known as the Zimbabwe Agenda for Sustainable Socioeconomic Transformation (ZIMASSET). More so section 298 of the Constitution of Zimbabwe amendment number 20 of 2013 alludes that revenue raised nationally must be shared equitably between central government and provincial and local tiers of government. However the finances fall far short to suffice development initiatives required to improve the issues of governance and in the process meeting its objectives. The problem here is that the share is too little to cover all the activities in the Ministry and having such a situation the District Administrators office is subject to receiving little if not nothing at all thus undermining its relevance. More so the relations that exists between the Central Government and the Local Government in Africa tend to impact negatively on the local government financial resources management (Davison 2001). Noting further lack of finance at the district level jeopardizes the provision of service delivery to the people. It should be noted that financial resources play a pivotal role in the process of sound local governance as it is biblically asserted that money answers everything.

\section{Creation Of Metropolitan Provinces}

The genesis of the provincial office a sub national structure was as a result of the Prime Ministers directive of 1984-85. The creation of the province was rather a political move rather than rationality with the propensity to recentralize power which is to the detriment of good governance as District Administrators urban areas are facing a lot of confusion and resistance from the council and stakeholders (Jonga 2014). It should be noted that the District Administrators' office came as a result of the Prime Minister directive of 1984-85 which resulted in the urban and rural councils merging. Jonga (2014) reiterated that these are subnational offices from the Provincial Administrator' level. He goes on to argue that the creation of these structures pose a challenge to the smooth functioning of urban local authorities. In addition, with conviction political expedience was a noteworthy danger in the running of the service along these lines for this frustrates the accomplishment of the objectives, mission and vision. This brought about the notion that the presentation of the workplaces of District Administrators (da) in urban areas, has been highlighted by a few leaders who felt it as a procedure by government to meddle with their operations and to drive them additionally to answer to Zimbabwe African National union Patriotic Front (ZANU PF) delegated functionaries (the financial gazette, 2003). However the Zimbabwe Institute (2005) alluded that observers and critics saw this move to appoint District Administrators and Provincial Administrators as a move to destroy the Movement for Democratic Change (mdc) party. Which had controlled the two cities by winning the local elections. Therefore this was a political move as opposed to discernment and objectivity in that capacity. It was uncovered that such workplaces were not accommodated in the Urban Councils Act (GOZ 1996) that is to say they are illegal. Thus they face resistance from the council and the people at the local level for they are seen as ZANU PF puppets. It suffice for one to argue that, it is the reason there is absence of political will to realign the laws in order to incorporate the District Administrators in the act. So the assurance is held in lack of clarity, its future blinks and its order is buried in extraordinary discussion. The presence of various individuals with various political belief systems in the service represent a danger to the smooth working of the service to convey administrations to the general population productively and viably. 


\section{Successes}

\section{Fig3: The Relationship Between The District Administrators Office And Stakeholders.}

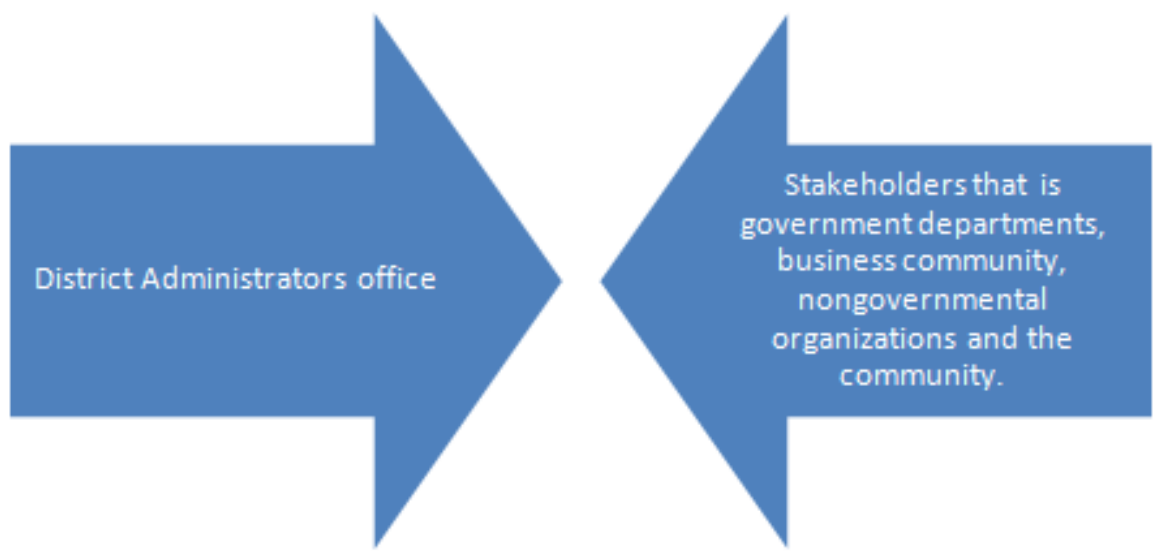

Source; Field Survey 2016 March

The District Administrators office come into the picture to assist in the coordination of several stakeholders that are involved in the development of the local area.is not an isolated structure in the development of Zimbabwe, it rather functions in partnership with various stakeholders such as Nongovernmental organizations (ngos),Local Authorities, Government Departments, Business Community. In doing this work the District Administrator expects a lot of cooperation from council. It is of utmost importance to note that Non-governmental organizations are of varied backgrounds and with different initiatives, some are local and regional with international links (Zimbabwe Institute 2005). Taking for instance in Mbare many poverty eradication schemes have been launched with the help of Non-governmental organization like Oxfam (District Administrator office). Active coordination by the District Administrator Harare Central has been instrumental in poverty eradication to such an extent that a Youth Resource Centre has been established to provide network opportunities as well as resources for learning opportunity seeking in form of information technology. More so, Straight Part Support Resource Centre and Young Voices Network an Ngo was said to be one of the organization that has contributed immensely to social development through rehabilitation of children living in the streets as well as empowerment of general women and youth thus positively impacting on the fundamental objective of the nation's Zimbabwe Agenda for Sustainable Socio-Economic Transformation (ZIMASSET) programs (Non-governmental file Harare Metropolitan Province). As a result of these moves, District Administrator Harare Central has been recognized for the job well done.In addition the developmental coordinative role played by the District Administrator in various programs has been the panacea to the success of developmental initiatives in the district. Through coordinating programs carried out by various stakeholders in the district, the District Administrator can provide relevant data for stakeholders that can help them to identify other stakeholders. In other words, the District Administrator facilitates coordination of other stakeholders in the district hence catalyze communication between stakeholders. Coordinating stakeholders in the district also acts as a tool for monitoring stakeholders that is to see if their operations are not politically biased and stakeholders are not carrying out seductive programs.

\section{Housing Delivery}

Land is a basic livelihood commodity that if not dealt with properly causes conflicts (Chirisa and Muhomba 2013). One has to take into cognizance that due to rapid urbanization a lot of pressure has been exerted on the national and local government internationally in relation to the availability of land, water and resources (Kessides 2006, Potts 2009, Tannerfeldt and Ijung 2006, World Bank 2010). Kessides (2006) further postulates that the pressure on the available land, water and resources has led to conflicts between the central and local government in a bid to satisfy demand for affordable orderly land and housing. Informal settlements in the world are estimated to be close to a billion internationally and this number is expected to double up by year 2030 (Payne and Majale 2004) however the District Administrators (das) have registered commendably in the area of housing delivery system, they have done so by way of proper organization of housing cooperatives. They are said to have actually brought sanity within the housing sector in terms of proper management of 
cooperatives, conflict resolutions, settling disputes among the management of housing cooperatives. Thus District Administrators have managed to assist housing cooperatives gain access to state land as they are the custodians of the local government.

Their position has even gone further in unearthing corruption in the local authorities as they have managed housing cooperatives of which this is the sector were corruption has been rampant. Thomas Mapfumo once sang "something for something, nothing for nothing", in the song corruption, the Chimurenga music guru had seen the cancerous social evil that had begun to slowly creep into our public even private institutions a few years latter corruption became a public secret that spread faster than a spring wildfire. Corruption in local authorities is dysfunctional and retrogressive and goes against the grain of development its effects are catastrophic and in most cases burdens the general populace at large thus with the inception of the District Administrators office urban areas corruption was and is being dealt with.

\section{Disaster Risk Management}

The concept of disaster management has evolved over the years to graduate to what is known as disaster risk management (Drm) incorporating all positive changes on how they are addressed in Zimbabwe (Bongo etal 2013). Drm particularly infers components of data administration, counteractive action, moderation and strengthening resilience, readiness and reaction and early recuperation (Government of Zimbabwe 2011).therefore the government's commitment to disaster risk management has led to a much stronger stakeholder participatory impetus with the creation and development of the draft 2011 disaster risk management strategy and the draft 2011 disaster risk management bill and policy in a bid to restructure and strengthen the department of Civil Protection to the department of Disaster Risk Management (Zimbabwe Country Analysis Working Document final draft 2014).

The office of District Administrators in urban areas has been very instrumental in disaster risk management as a stakeholder, there are responsible for steering the committee that oversee disasters (Civil Protection act 10:06). They discuss and embark on possible solutions and take the center role in the implementation of strategies that curb disasters. This paves way for further development in the district. It is said that not planning is actually planning to fail therefore many plans, activities and workshops were carried out in the district in a bid to mitigate the impact of disasters. It is the function of the District Administrator to chair and monitor all plans on disaster preparedness of the area concerned as reiterated in the Civil Protection Act chapter 10:06.in the process of mitigating disasters the researcher managed to catch a glimpse of a brief overview of the minutes on urban flooding noting the state and impact of flash floods in the district following the heavy rains recorded from the last week of December 2014 to the first week of January 2015 in the Harare Central District. Most of the roads in the district were dilapidated, houses were destroyed and temporary structures were destroyed as well (Provincial Administrators weekly report as at 2 January to 9 February 2015). The District Administrator's office responded quickly and an urgent civil protection meeting was held and a tour was carried out in the areas affected (2014 December Harare Central District weekly report). The tour was led by the District Administrators thereby revealing the importance of das in local government. It is also another administrative responsibility of the district office to write letters of operation to well-wishers and organizations. The researcher found that it once happened that the Global Critical Rescue Trust a Non-profit making organization was seeking to register in the district with the main motives of encouraging citizen participation in national disaster management, capacity building and maintaining highest standards of professionalism and integrity. The main thrust of the district office hereto was advising the organization on what course of action to take. The District Administrator is accountable for everything that transpires within the district thus it is imperative for the organization to be well versed with the rules and regulations before its operation and the consequences faced in case they breach the rules and regulations thus the District Administrator office is of utmost importance. It is upon this juncture that one cannot deny that they are with their successes.

\section{CONCLUSION}

The creation of the Metropolitan Provinces and the introduction of District Administrators in urban Zimbabwe was a move to upgrade governance in an area that has several problems like poverty, service delivery, crime lack of resources. The cadre was introduced in 2004 and since then no specific legislation has been put in place and in Harare five(5) District Administrators manage one local authority head office is also in this district creating another authority. There is duplication of authority and it has resulted in defiance from the local authority as it prefers to deal with head office. The absence of other structures like Traditional Leadership, Village Development Committees and Ward Development Committees has also made coordination with the grassroots difficult. However the district administrator has scored success in area like coordination of different stakeholders, housing delivery management and disaster risk management.

\section{REFERENCES}


[1] Bongo P.P., Chipangura, P., Sithole M. And Moyo F, 2013, A Rights Based Analysis Of Disaster Risk Reduction Framework In Zimbabwe And Its Implications For Policy And Practice, In Journal Of Disaster Risk Studies 5(2) Article 81.

[2] Chikerema, A.,F., (2012), Citizen Participation And Local Democracy In Zimbabwean Local Government System, In Iosr Journal Of Humanities And Social Science (Iosr-Jhss) Volume 13, Issue 2 (Jul. - Aug. 2013), Page 87-90.

[3] Chirisa. I AndJonga. W, (2009), Urban Local Governance In The Crucible: Empirical Overtones Of Central Government Meddling In Local Urban Councils Affairs In Zimbabwe. Accessed On 20 January 2016. Retrieved At Https://Www.Researchgate.Net/Publication/26842227.

[4] Constitution Of Zimbabwe Amendment (No. 20) Act, 2013.

[5] Combined Harare Residents Association (2014), The Green Paper On Zimbabwe's Local Government, Newlands, Harare

[6] Goz (Government Of Zimbabwe) (1996). Urban Councils Act Chapter 29:15, Government Of

[7] Zimbabwe: Harare

[8] Goz, 2011, Disaster Risk Management Strategy 2012-2015, Draft 1

[9] Jonga, W (2014), Local Government System In Zimbabwe And Associated Challenges: Synthesis And Antithesis, Archives Of Business Research, Vol.2 No.1

[10] Kurebwa, J. (2014), A Review Of Rural Local Government System In Zimbabwe From 1980 To 2014.Iosr Journal Of Humanities And Social Science (Iosr-Jhss) Volume 20, Issue 2, Available Atwww.Iosrjournals.Org, Accessed On 13 March 2016.

[11] Matyszak, D. (2011). Formal Structures Of Power In Rural Zimbabwe. (Www.Researchandadvocacyunit.Org) Accessed 15 March 2016.

[12] Mushamba, S., Bhoroma, L., Chirisa, I. And Chaumba, A.M (2014), A Research Report On The

[13] Dynamics Of Devolution And The Impact On Youth Participation In Local Government In

[14] Zimbabwe, Edsaction Aid Denmark.

[15] Ncube, G. T. (2011),Crisis Of Communal Leadership: Post-Colonial Local Government Reform And Administrative Conflict With Traditional Authorities In The Communal Areas Of Zimbabwe, 1980-2008, African Journal Of History And Culture Vol. 3(6), Pp. 89-95, Available Online At Http://Www.Academicjournals.Org/Ajhc Accessed On 14 February 2016.

[16] Payne, G. And Majale, M., 2004. The Urban Housing Manual, Making Regulatory Frameworks Work For The Poor. London: Earthscan.

[17] Provincial Councils And Administration Act Chapter 29:11.Rural District Councils Act Chapter 29: 13

[18] Tannerfeldt, G. And Ljung, P., 2006. More Urban Less Poor: An Introduction To Urban Development And Management. London: Earthscan.

[19] The Financial Gazette (2003, February 27 - March 5) HarareUrban Councils Act Chapter 29: 15.

[20] De-Visser, J., Steytler, N. And Machingauta, N. (2010),Local Government Reform In Zimbabwe, Western Cape: University Of Western Capepublications.

[21] Zimbabwe Country Analysis Working Document Final Draft 3 October, (2014), Available At Http://Www.Zw.One.Un.Org/Sites/Default/Files/Publications/Unzimbabwe/Country\%20analysis_Finalre view_3oct2014.Pdf.Accessed On 24/02/2016,

[22] Zimbabwe Institute, (2005) Local Government: Policy Review, (Online) Available At

[23] Www.Kubatana.Net/Docs/.../Zim_Institute_Loc_Gvt_Paper_0506.Doc(8 October 2012). 